\title{
Pitiakhshs in Iberia in Classical Epoch
}

\author{
Zurab Bragvadze \\ Georgian National Museum, 0108 3, A. Purtseladze str., \\ Tbilisi, Georgia \\ zbragvadze@yahoo.com \\ DOI: https://doi.org/10.52147/2667-9353/2021-1-51-59
}

\begin{abstract}
Artifacts found in Village Bori in 1902 are kept in the Hermitage in Sankt Petersburg. Among the finds particularly interesting is a silver cup with an Aramaic inscription:" Kind Pitiakhsh Buzmihr". The inscription revealed that there existed an institution of pitiakhsh in the kingdom of Iberia in Roman epoch. Indeed, it is interesting whether the grave which yielded the mentioned object was the tomb of a pitiakhsh. The point is that in Bori no sarcophagi or crypts are encountered, there are only pit-burials there which, in my opinion, excludes presence of a pitiakhsh's tomb in the area and the rich inventory recovered together with the bowl in question does not belong to a pitiakhsh. It is more likely that the bowl had been presented by Pitiakhsh Buzmihr. The Roman-period kingdom of Iberia knows a few similar cases. But where exactly is Pitiakhsh Buzmihr's grave? The question has not been answered yet. Apart from other issues, the article deals with the chronological order of the pitiakhshs of Armaziskhevi cemetery and suggests that pitiakhs are buried only in graves NN 1, 2 and 3. Furtheremore, it discusses the problem of interrelationship between the pitiakhs' graves and the structures found in Armaziskhevi and passes an opinion that the structures date to an earlier period than the graves. In the $70 \mathrm{~s}$ (not later than $75 A D$ ), the residence was destroyed by an earthquake and since then the area was used as a cemetery of pitiakhshs of Armaziskhevi and their family members.
\end{abstract}

Key words: pitiakhsh, Iberia, Armaziskhevi, Bori

Introduction. Since the late 1930s, when archaeological excavations at Armaziskhevi revealed graves of high-ranking officials of the kingdom of Kartli and Greco-Aramaic inscriptions, interest in the social-political institution of pitiakhshs has not waned. Many scholars have tried to find out about its essence, have expressed their opinions about Armaziskhevi and, in general, the instituttion of pitiakhshs in their scholarly works.

Body. In 1902, a silver bowl with an image of a horse in front of an altar and an Aramaic inscription was accidently found while farming the land in Bori. The inscription and, accordingly, the date of the silver bowl have sparked controversy (E. Pridik, A. Borisov, S. Amiranashvili, G. Tsereteli), but non of the scholars have any doubts about the content and reading of the inscription, and all of them agree that it says "Kind Pitiakhsh Buzmihr". It should be noted that the bowl of Bori was the first archaeological artifact which provided basis for estimating presence of the office of the pitiakhsh in Classical-period Georgia and it antedates the renowned Armaziskhevi discoveries by three decades. Because of the fact that the archaeological artefacts of Bori were revealed at different times and, at the same time, are recovered by so-called 'black archaeologists', it remains impossible to arrange them in sets; moreover, it is unknown how many graves could have been there and whether these materials come from the same cemetery. As is known, Bori cemetery enompassed a rather vast territory and it is also clear that there were different kinds of graves here (pit-burials and pithos burials). Therefore, it cannot be excluded that we are dealing with at least two necropolises. It is also true that the archaeological materials ended up in the museums of Petersburg, as well as the Georgian National Museum, without any archaeological context, which is what makes estimation of even the approximate number of the graves complicated. Discoveries of Armaziskhevi play an extremely important role in estimating the definition 
of the archaeological collection of Bori. The inventory of the burials of Armaxiskhevi pitiakhshs makes it possible to identify pitiakhshs' possessions, or the artifacts that were inevitable attributes for the hierarchs of the kingdom of Kartli (Iberia). In my opinion, among the burials investigated in Armaziskhevi, the pitiakhshs must have been buried in graves NN 1, 2 and 3, while the rest of the rich burial complexes of the second-third centuries do not belong to the pitiakhshs' tombs and they must belong to other representatives of this family [see below].

The first (Asparug's) grave of Armaziskhevi yielded the following: gold signet ring, gold belt, gold foil of a sword-sheath, gold diadem, gold appliques, gold coins, three silver bowls, two silver bowls with two handles, two silver jugs, silver mirror, silver buckles, silver plaques, silver bed legs, bronze buckle, two iron knives, paste beads, glassware, bone object and remains of wood.

The second (Armazes') grave of Armaziskhevi contains: gold bracelet, gold medallion, five gold rings, gold earrings, gold pendant, gold amulet case, gold buttons, gold coins, silver cup, glassware. The third (Bersuma's) grave of Armaziskhevi revealed: dagger with a gold hilt, gold finger-ring, gold plates of a diadem, gold earring, two gold pendants, gold coins, silver bowl with the image of a horse in front of the altar and Aramaic inscription, bed legs. These three graves contain different numbers of artifacts that vary between 17 and 37 (24 items in Bersuma's grave, 17 - in Armzes' grave and 36 - in Asparug's grave). Therefore, the grave goods evidenced in these graves are necessary attributes characteristic only to pitiakhshs' tombs. Indeed, in respect to reconstruction of Pitiakhsh Buzmihr's grave, it is important to compare the artifacts found in all three graves of Armaziskhevi to the collection obtained at Bori. In my opinion, in terms of the number of artifacts and their resemblance, Buzmihr's grave is closest to Asparug's and Bersuma's graves and there must have been up to thirty items here. It should also be mentioned that cups with horses are not common only to pitiakhshs' graves. They are also encountered among the grave goods buried along with dignitaries of Iberia (Zghuderi). The same is true for beds, too, that are common funerary items of representatives of noble families in the kingdom of Iberia (Zghuderi, Akhali Zhinvali). As far as the metal (bronze and silver) jars are concerned, they are evidenced in the graves that belong to preveleged members of society, rather than pitiakhshs (Zghuderi, Ertso). Neither are gold signet rings found solely in pitiakhshs' graves. In this respect we should mention graves of Zghuderi, where they were revealed in three rich tombs. The same can be said about daggers decorated with gold and diadems - the former was found in a burial in Modinakhe, the latter - among late-Roman period artifacts discovered in grave N66 in Modinakhe.

Thus, it seems impossible to set apart the items that must be common to only pitiakhshs' graves. However, it just seems so, as in this case central importance is attached to the factor of chronology and the type of burials. Pitiakhshs' graves are sarcophagi. This type of sarcophagi are typical of only Armaziskhevi necropolis, while there are just ordinary pit-burials in Akhali Zhinvali, Ertso, Urbnisi and Modinakhe. The Armaziskhevi sarcophagi might look like the Zghuderi ones, but they are still different. As for Bori, we are unable to consider the type of the graves or the burial rite, as we do not possess any information about these topics. However, it is probable that we must be dealing with a pit burial in the case of Bori, too. At the same time, it should be noted that the graves of Magraneti (Ertso), Akhali Zhinvali, Urbnisi and Modinakhe chronologically differ from the complexes of Armaziskhevi and belong to the fourth century, or the period when the Armaziskhevi branch of pitiakhshs did not exist any more. As a consequence of this fact, resemblance between the grave goods of these complexes is only outward, rather than contentual. Thus, it is impossible to regard the artifacts as being designed solely for pitiakhshs' graves according to metalware, bed legs, silver bowls with horses and gold signet rings, as they might be found in graves of other dignitaries as well. It should also be emphasized that while in the first-third centuries pitiakhshs of Iberia seem to be state officials loyal to Rome (the artifacts re- 
vealed in the graves of Armaziskhevi and Bori evidence the same, as their majority is of Roman origin), in the early Middle Ages pitiakhshs already display their obedience towards Sassanid Iran (Varsken, Pitiakhsh of Kvemo Kartli). However, it seems unlikely that the pitiakhshs of Iberia had any opportunity of carrying out their own foreign policy. This circumstance is directly connected to the alternation of the country's foreign vectors. In the Classical epoch Iberia was a country loyally disposed towards Rome and at the time the influence of the Sassanid Ran in South Caucasia was not as conspicuous as in the fifth-sixth centuries. Pitiakhsh Buzmihr must have ruled in the second half of the third century. In this respect he is contemporary of Pitiakhsh Armazes of Armaziskhevi. The period of his governance coincides with the end of presence of Iberian pitiakhshs. From then on, the office of pitiakhsh in the kingdom of Iberia either declines or ceases to exist and reinstitution of this position of power occurs later, at the beginning of early Middle Ages, probably in the mid- or the late fourth century. However, the pitiakhshs of this epoch differ from those of Classical-period Iberia primarily by the fact that they apparently followed a policy of Sassanid Iran.

Discovery of a single artifact in the name of a single third-century pitiakhsh in the region of Argveti (Bori) does not mean that an administrative unit of Iberia was created in Zemo Imereti at this very time and there had not existed such a body before. A major reform was carried out at the turn of the new era, which implied division of the country into administrative-territorial units. One of these units was formed in the region of Argveti and, in my opinion, it was founded at the end of the first century BC under King Parnavaz II. Nevertheless, there are issues that still remain unclear: where are the first-third-century pitiakhshs of Argveti buried and, accordingly, where was their residence situated? At the moment it is also unknown where the residence of Pitiakhsh Buzmihr was situated.

It has already been discussed above that it is difficult to identify the artifacts that are exclusively typical of Pitiakhsh graves. It is even more difficult to do so in Bori collection. Only one item - the bowl with a horse -raises no doubts as to belonging to a pitiakhsh. However, there is a question: how far can we consider the grave which yielded this bowl as a tomb of a pitiakhsh? The point is that neither sarcophagus nor crypt have been evidenced in Bori. According to all the sources, the artifacts belonging to Pitiakhsh Buzmihr come from an ordinary pit burial. This fact leads me to suggest that in this case it should not be a pitiakhsh's grave and the rich inventory revealed there probably did not belong to a pitiakhsh. Among the finds of Bori it is only in crypts and sarcophagi that the insignia of the ruling class common to the graves of Armaziskhevi pitiakhshs (diadem, signet ring, dagger in a gold sheath) can be found. At a glance, the silver bowl with an inscription makes the situation even more complicated. However, it is not excluded that it was presented by Pitiakhsh Buzmihr to the person buried in Bori. In Roman period it was quite a common practice for governors to present their subordinates with precious items with memorable inscriptions. Let us recall a bowl gifted to Pitiakhsh Bersuma. Therefore, if we accept this suggestion, then we could find answers to the following questions: why is the pitiakhsh's bowl with an inscription found in a pit burial, rather than in a crypt or sarcophagus? Why aren't the insignia of the ruling class typical of pitiakhshs encountered here? In my opinion, it is the person who the silver bowl belongs to that is buried in Bori. He was a pretty wealthy person and must have had close relationship with the ruling class of Iberia. It is proved by gifting him with a precious object by a pitiakhsh. In this case the situation is identical to that of Zghuderi, where a silver tray buried along with a rich individual was evidenced.

Research of the office of pitiakhsh became particularly topical following the discoveries of Armaziskhevi. In my opinion, the key person in the house of pitiakhshs of Armaziskhevi is Asparug. All the known persons of Armaziskhevi necropolis are linked to him and Asparug is the clue for all of them. Next to him is buried Karpak, who, indeed, cannot be considered his spouse because of the inscrip- 
tion "Zevakh is my life". This woman is buried next to Asparug. Accordingly, she must be his family member, probably daughter. Karpak's husband is Zevakh. The latter must be Seraphita's father, i.e. Seraphita is Asparug's granddaughter and Karpak's daughter. On the other hand, Seraphita's father Zevakh is a minor pitiakhsh. Due to lack of proper facts, we are unaware where Zevakh is buried. His grave is not found in Armaziskhevi. Does it mean that it is admittable that minor pitiakhshs had their own necropolis? Then why is his wife buried next to her father rather than next to him? The fact that Seraphita is buried in Armaziskhevi is even more confusing. She is a married woman and her husband is lodmangan, the royal housekeeper that ranked higher than pitiakhshs. There can be only two suggestions: both Karpak and Seraphita died in Asparug's lifetime and Asparug saw to it that his son and granddaughter would be buried at the family cemetery, or, simply, it was an accepted practice for the aristocracy of the time to bury daughters in fathers' estates. Although Zevakh is a pitiakhsh, too, apparently, the rank of a minor pitiakhsh did not allow to contradict Asparug.

Bersuma is the second pitiahsh on the cemetery. Presumably, he is Asparug's successor and his son, while Asparug himself is the son of Sharagas.

The theory developed by Andria Apakidze. In his monograph 'Towns and Urban Life in Ancient Georgia' Andria Apakidze changed the opinion expressed together with his co-authors in 'Mtskheta I' and recognized only the graves of Asparug and Bersuma as those of pitiakhshs, while he attributed graves NN 2, 6, 7 and 9 to the family members of pitiakhshs. According to the scholar, Zevakh (Javakh), mentioned in the bilingual inscription, was Asparug's son and, at the same time, pitiakhsh of King Parsman. Furthermore, he pushed the date of Asparug's pitiakhsh signet ring back and considered it contemporary to the stela of Sharagas. By this he attempted to identify Pitiakhsh Asparug with the Asparuk mentioned in the inscription of Sharagas, by which, somehow, chronological irrelevance and the order of succession were regulated. However, if Asparug's grave dates from the second century, how could the Asparug living in the first and the second centuries the same person? Therefore, this must be an attempt of artificial identification of two different individuals. In order to support his opinion, A. Apakidze considers that grave N1 of Armaziskhevi does not belong to Asparug, whose pitiakhsh signet ring was uncovered there, but to his son Zevakh (Javakh) the minor. This assumption might have been challenged by Asparug's pitiakhsh signet ring, but the explanation was found here as well. He suggested that the signet ring belonged to Asparug and it was buried along with his son Zevakh. In order to substantiate this opinion, the scholar cites several occasions from the sarcophagi of Armaziskhevi and Bagineti gateway. There are three Greek letters 'ZVX' carved out on a signet ring discovered in grave N2 of Armaziskhevi, and a silver spoon with an inscription 'king's' was recovered from the crypt of Bagineti gateway. Nevertheless, the grave belongs to a princess, rather than a king. Grave N6 of Armaziskhevi yielded a finger ring with an inscription 'Zevakh' (Javakh). It is not excluded that the ring belonged to one of the children of Zevakh (Javakh) the minor. It turns out that the children were buried along with signet rings and finger rings with their father's name on them. Neither did G. Tsereteli exclude sameness of Zevakh mentioned in the inscription made on the gold buckle of Karpak and that from Seraphita's inscription. However, he did not share the assumption about identity of this Zevakh and the one mentioned in the stela of Sharagas because of a century-long difference between them. By recognizing Asparug's grave as that of Javakh A. Apakidze outlined the dynasty of Kartlian pitiakhshs, i.e. the dynasty of Javakhs: Sharagas' father Javakh, Sharagas' nephew Javakh the Younger and Asparug's granddaughter Seraphita. However, if we follow this logic, everything might turn upside down. For instance, Karpak's grave might be the grave of the daughter of hers and Zevakh's, and an artifact showing eternal love of her parents might be buried along with her ('Zevakh is my life'); Bersuma's grave might belong to his son and his father's cup with an inscription might be buried along 
with him in honor of his father, and so on. Therefore, it turns out that not the individuals mentioned in the inscriptions of Armaziskhevi are buried here, but their children, while the location of the grave of pitiakhshs mentioned in the inscriptions remains unknown.

Previous viewpoint about Searphita's grave has been revised too. In the collection dedicated to the archaeological research of Armaziskhevi grave N 7 is recognized as Seraphita's tomb, while in the monography published in 1963 - it is grave N6, where, according to the original version, Karpak is buried. It should be noted that recognizing grave N7 as Seraphita's tomb arises many questions because, apart from outward appearance and diversity of the inventory, there is no other argument to support this fact. However, even if it was not Seraphita's grave, it does not make a difference in the topic we are interested in, as the women (Seraphita, Karpak) rested in rich graves are members of pitiakhsh families rather than pitiakhshs themselves. The problem of the stela of Sharagas is also considered in an interesting and peculiar way. According to A. Apakidze, the stela must have originally been erected in Mtskheta. This opinion was shared by G. Abramishvili, who regarded the stela as the memorial to King Mithridates of Iberia. However, none of the authors have provided convincing arguments for why the stela should have stood in Mtskheta and upon the king's tomb, or who the individual buried in grave N4 of Armaziskhevi should be so that his grave was arranged with the king's memorial specially brought here from Mtskheta. In addition, if we take into consideration that one side of the tomb is Seraphita's epitaph, then it must have been a superior person in the society of Kartli at the time. Obviously, it is not the case and it is more admittable that grave $\mathrm{N} 4$ belongs to the period when the society had long forgotten Armaziskhevi and pitiakhshs, when graves of pitiakhshs (Sharagas) and their family members (Seraphita) are not regarded as sacred and untouchable any more. Memory of these graves had also vanished and the only thing that had survived and had been visible is stelas used for arranging new graves. Therefore, it seems more convincing that the stela of Sharagas, just like Seraphita's epitaph, had stood at Armaziskhevi necropolis from the very beginning and they had not been brought from anywhere else. Considering the factors that there are stelas built in it, excavators of the site regard grave N4 as a tomb of a pitiakhsh. The grave has been robbed and does not contain a single artifact. Therefore, its date can only be estimated by means of the stelas. It becomes clear that it cannot be considered as a complex contemporaneous with pitiakhshs and their family members due to a simple reason that no one would demolish and violate integrity of the tomb of two aristocrats for a grave of a pitiakhsh. It would be more sensible to assume that the person buried in grave N4 has nothing to do with the family of pitiakhshs. Obviously, he is not a pitiakhsh and did not live in the times of Armaziskhevi pitiakhshs. Consequently, the grave must belong to a later period $\left(4^{\text {th }} \mathrm{c}\right)$. At least it was arranged when the house of Armaziskhevi pitiakhshs had already broken its social and political continuity.

The theory developed by Shalva Amiranashvili. It is highly likely that a pitiakhsh was buried in grave N2 as well. In this respect the most important and crucial factor is presence of the silver cup portraying a Sassanid nobleman in the grave. Scholars' special attention is attracted by the inscription of the cup executed in Middle Persian (Pahlavi). According to G. Tsereteli's translation, the inscription is interpreted as follows: "Pitiakhsh of divine Ardashir, son of divine (Papak?)". G. Tsereteli suggests that the Persian dignitary portrayed in the center of the cup must be the founder of this dynasty Ardashir I. S. Amiranashvili expresses a different opinion according to which it is not Ardashir I, but Pitiakhsh Papak depicted on the cup. In addition, S. Amiranashvili interpreted the inscription differently from G. Tsereteli: "Papak Pitiakhsh of divine Ardashir, of the son of divine Papak presents to Armazes, pitiakhsh of the country of Gurzan." The opinion that the depicted person is Pitiakhsh Papak is shared by K. Trever and M. Lukonin. Nevertheless, hardly anybody paid proper attention to the opinion expressed by 
S. Amiranashvili, according to which the inscription in question mentions Pitiakhsh Armazes. Nobody has accepted or denied this opinion in scholarly literature. On this stage of research, it can be noted that there is no objective reason for not agreeing with or sharing S. Amiranashvili's above-mentioned opinion in respect to mentioning Pitiakhsh Armazes in the inscription. Consequently, grave N2 of Armaziskhevi, which dates to the second half of the third century can be considered to be the grave of Pitiakhsh Armazes. The fact that a noble woman is buried in grave N2 does not change the picture. There are quite a few occasions in the history of Classical-period Georgia and its archaeology when women carry out the supreme authority of a certain governing unit. In this respect, suffice it to mention well-known discoveries of Sairkhe, Itkhvisi and Vani.

Problem of interrelationship between the pitiakhsh's residence and graves. It is necessary to express an assumption in respect to the interrelationship between the pitiakhshs' cemetery and the extant structures. Authors of 'Mtskheta I' believed that the four structures preserved in Armaziskhevi (those with a threshold, a single room, a double room and a bathhouse) must have been contemporary to the pitiakhshs' graves and operated in the second-third centuries. A. Apakidze expressed a different opinion and recognized the so-called double-room structure as a mausoleum or a chapel and associated the date of its construction to that of arranging Asparug's grave -the second half of the second century.

These problems are interpreted differently by K. Khimshiashvili. Based on investigation of proper parallels and building technique of the structures, he believes that the structures of Armaziskhevi and graves of governors and pitiakhshs are not contemporary and that the structures were used for accommodating graves when they had already been destroyed. Consequently, by the second half of the second century the constructions existing here had already been ruined and the scholar dates them to the first century- beginning of the second century. In my opinion, K. Khimshiashvili's viewpoint sounds most convincing. Let alone the architectural context, it is difficult to imagine that a pitiakhshs' residence, a bathhouse and a cemetery operated on such a small area the same time. Even ignoring the chronological irrelevance, resulting from sanitary and hygienic norms, it is almost excluded to arrange a cemetery at a distance of a few meters from a residence and a bathhouse. It is an unusual practice for the Hellenistic-Roman period and, in this respect, Armaziskhevi cannot be an exclusion. This viewpoint about the date of destruction of the structures in Armaziskhevi and the reasons causing it expressed by K. Khimshiashvili can be specified by considering the data of another benchmark site of Shida Kar$\mathrm{tli}$ - Dedoplis Gora. It is noted in scholarly literature that the palace of Dedoplis Gora must have been destroyed by a strong earthquake at the end of the first century AD. Written sources do not provide any information about major destruction or calamity connected to military activities in the kingdom of Kartli in this epoch. It is the epoch of the reign of great kings Parsman I and Mithridates II. It is clear from the inscription of the stela of Sharagas discovered in the same Armaziskhevi that kings of Kartli of the time are "winners of many victories". That is why I. Gagoshidze rightly links the destruction of the palace of Dedoplis Gora with an earthquake, rather than hostilities. Apparently, the tremor was so strong and caused such destruction to the palace of Dedoplis Gora that nobody ever thought about its restoration. It is possible that it was this earthquake that brought about collapse of the structures in Armaziskhevi. If this assumption is correct, then it supports the date offered by K. Khimshiashvili and provides grounds to think that the facilities in Armaziskhevi operated from the end of the first century $B C$ to the 70s AD (see below). It is this period that is characterized by unprecedented, intensive construction activities in the kingdom of Kartli. In this respect relationship between Kartli and Rome must have been the crucial factor. It can also be assumed that the famous inscription of Vespasian discovered in Mtskheta in 1867 speaks about consolidation of the walls affected by this very earthquake. If 
so, then it comes out that in Kartli the strong earthquake that devastated residences in Dedoplis Gora and Armaziskhevi and badly affected fortified walls of Mtskheta must have occurred in the 70s, not later than $75 \mathrm{AD}$.

As far as emergence of the office of pitiakhsh in the kingdom of Kartli is concerned, the end of the first century BC, or, at least, the beginning of the first century AD can be assumed as its lower chronological border because, resulting from the political situation, it must have been at the time that administrative units of the kingdom of Kartli - principalities or pitiakhshs' domains - were formed.

Conclusion. Thus, despite the fact that in my opinion, no grave of a pitiakkhsh is evidenced in Bori, the artifacts obtained in this village have great importance for the history of Iberia of Roman epoch, as another name of a pitiakhsh is revealed. However, it remains unknown where Pitiakhsh Buzmihr is buried. Accordingly, it is not clear whether Kind Pitiakhsh Buzmihr comes from the Armaziskhevi house of pitiakhshs or is the pitiakhsh of Argveta. He must have been a pitiakhsh of Argveta, because no pitiakhsh bearing this name is known from Armaziskhevi. As for Armaziskhevi pitiakhshs, if the expressed viewpoints are close to reality, then it can be assumed that there is a total of three pitiakhshs known from Armaziskhevi cemetery and graves NN1, 2 and 3 are their tombs, while the chronological order of the pitiakhshs would be as follows: Asparug (grave N1), Bersuma (grave N3) and Armazes (grave N2). The time period between the second half of the first century and the second half of the third century are identified as the period when Armaziskhevi pitiakhshs ruled. Although no graves of Sharagas and his father Pitiakhsh Zevakh, living in the first century, have been discovered, there is no doubt that Zevakh is the first pitiakhsh of Armaziskhevi rulers. Consequently, the order of Armaziskhevi pitiakhshs is as follows: Zevakh-Sharagas-Asparug-Bersuma-Armazes. Thus, there are five pitiakhshs buried in Armazisjhevi, which is quite acceptable for the period of two centuries. Graves of three of them have been identified, while two of the robbed graves could belong to Zevakh and Sharagas. The mentioned territory of Armaziskhevi was the land belonging to pitiakhshs from the very beginning, where their residence, bathhouse and other facilities operated from the end of the first century $B C$ to the 70s AD. The earthquake caused destruction to almost all the structures and they were never restored. From the end of the first century AD, the area became the resting place for pitiakhshs and their family members, but location of their residence in the second-third centuries has not been identified so far. 


\section{Reference}

1. Kvirkvaya R. Davilianidze R. Chkhartishvili N. "Archaeological collections from the village Bori”, Bulletin of the Georgian National MuseumVII (52 B), p. 6-30, Tbilisi 2016 (In Georgian).

2. Mtskheta I. Archaeological excavations in Armaziskhevi. p.22-40. Tbilisi 1955 (In Georgian).

3. Mtskheta I. Archaeological excavations in Armaziskhevi. p.40-46. Tbilisi 1955 (In Georgian).

4. Mtskheta I. Archaeological excavations in Armaziskhevi. p.46-53. Tbilisi 1955 (In Georgian).

5. Braund D. Javakhishvili K. Nemsadze G. "The Treasures Of Zghuderi", Tbilisi 2009 (In Georgian).

6. Nadiradze J. “Archaeological Monuments of Kvirila Gorge”, p.67, Tbilisi 1975 (In Georgian).

7. Bragvadze Z." Kvirila Gorge in Late Antiquity", Iberia-Colchis, N3.p.124.Tbilisi (In Georgian).

8. Bragvadze Z. "For Some Historical-Archeological Problems of Iberia-Colchis", "Searches in Archeology of Georgia”, N 21, pp.248-255, Tbilisi.2013 (In Georgian).

9. Braund D. Javakhishvili K. Nemsadze G. "The Treasures Of Zghuderi", p. 21, Tbilisi 2009 (In Georgian).

10. Tsereteli G. "Greek inscription of Vespasian Epoch from Mtskheta”, p.33-34. Tbilisi 1958 (In Georgian).

11. Apakidze A. "Cities and Urban Life in Ancient Georgia”, p.110. Tbilisi 1963 (In Georgian).

12. Apakidze A. "Cities and Urban Life in Ancient Georgia”, p.115. Tbilisi 1963 (In Georgian).

13. Apakidze A. "Cities and Urban Life in Ancient Georgia”, p.115. Tbilisi 1963 (In Georgian).

14. Apakidze A. "Cities and Urban Life in Ancient Georgia", p.115. Tbilisi 1963 (In Georgian).

15. Apakidze A. "Cities and Urban Life in Ancient Georgia”, p.115. Tbilisi 1963 (In Georgian).

16. Apakidze A. "Cities and Urban Life in Ancient Georgia”, p.115. Tbilisi 1963 (In Georgian).

17. Apakidze A. "Cities and Urban Life in Ancient Georgia”, p.115. Tbilisi 1963 (In Georgian).

18. Tsereteli G. "Epigraphic finds in Mtskheta, the ancient capital of Georgia", Bulletin of Ancient History, N2, p.34. Moscow 1948 (In Russian).

19. Apakidze A. "Cities and Urban Life in Ancient Georgia", p.116. Tbilisi 1963 (In Georgian).

20. Apakidze A. "Cities and Urban Life in Ancient Georgia", p.117. Tbilisi 1963 (In Georgian).

21. Mtskheta I. Archaeological excavations in Armaziskhevi. p.46. Tbilisi 1955 (In Georgian).

22. Apakidze A. "Cities and Urban Life in Ancient Georgia", p.116. Tbilisi 1963 (In Georgian).

23. Apakidze A. "Cities and Urban Life in Ancient Georgia”, p.117. Tbilisi 1963 (In Georgian).

24. Abramishvili G. "Sharagas Stella and Problems of Georgian Cultural History. Essays by the State Museum of Art of Georgia. IX. p.36, Tbilisi 2004 (In Georgian).

25. Mtskheta I. Archaeological excavations in Armaziskhevi. p.46. Tbilisi 1955 (In Georgian).

26. Tsereteli G. "Epigraphic finds in Mtskheta, the ancient capital of Georgia”, Bulletin of Ancient History, N2, p. 55. Moscow 1948 (In Russian).

27. Tsereteli G. "Epigraphic finds in Mtskheta, the ancient capital of Georgia”, Bulletin of Ancient History, N2, p. 55. Moscow 1948 (In Russian).

28. Amiranashvili Sh. "Silver bowl of the Early Sassanian era found during the excavation of Armaziskhevi. Collection "Tbilisi - 1500"., p. 90-91, Tbilisi 1958 (In Georgian).

29. Amiranashvili Sh. "Silver bowl of the Early Sassanian era found during the excavation of Armaziskhevi. Collection “Tbilisi - 1500"., p. 89, Tbilisi 1958 (In Georgian).

30. Trever K., Lukonin M. "Sasanian Silver", p.42, Moscow 1984 (In Russian).

31. Mtskheta I. Archaeological excavations in Armaziskhevi. p.46. Tbilisi 1955 (In Georgian). 
32. Mtskheta I. Archaeological excavations in Armaziskhevi. p.40. Tbilisi 1955 (In Georgian).

33. Bragvadze Z. "Sairkhe The Center of Skeptukhia of Colchis Kingdom", Essays of the State Museum of Art of Georgia, N IV, p.64-74, Tbilisi 1998 (In Georgian).

34. Gagoshidze I., Gogiberidze N., Makharadze G. "Itkhvisi Cemetery", Archeological Journal.,V, p. 49-56, Tbilisi 2010 (In Georgian).

35. Lordkipanidze O. "Vani City Site (Excavations. History. Problems)". Vani I .p.7-42, Tbilisi. 1972 (In Georgian and in Russian).

36. Mtskheta I. Archaeological excavations in Armaziskhevi. p.159, Tbilisi 1955 (In Georgian).

37. Apakidze A. "Cities and Urban Life in Ancient Georgia", p.111-112. Tbilisi 1963 (In Georgian).

38. Khimshiashvili K. "Armaziskhevi Antiquity Buildings.", "Literature and Art". N 1-2, p.107-108. Tbilisi 1992 (In Georgian).

39. Gagoshidze I. "Archaeological Excavations in 2013-2015 at Dedoplis Gora", "Iberia-Colchis".

N 11. p. 120-121, Tbilisi 2015 (In Georgian).

40. Melikishvili G. "On the History of Ancient Georgia". p.337-345, Tbilisi 1959 (In Russian).

41. Makhardze G., Bragvadze Z. "For the history of the kingdom of Kartli in the II-I centuries B.C.". Essays of Art Museum of Georgia. VII. p. 59-60, Tbilisi 2001 (In Georgian).

42. Tsereteli G. "Greek inscription of Vespasian Epoch from Mtskheta", p.33-34. Tbilisi 1958 (In Georgian).

43. Bragvadze Z. "For Some Historical-Archeological Problems of Iberia-Colchis", "Searches in Archeology of Georgia”, N 21, pp.253, Tbilisi.2013 (In Georgian). 